
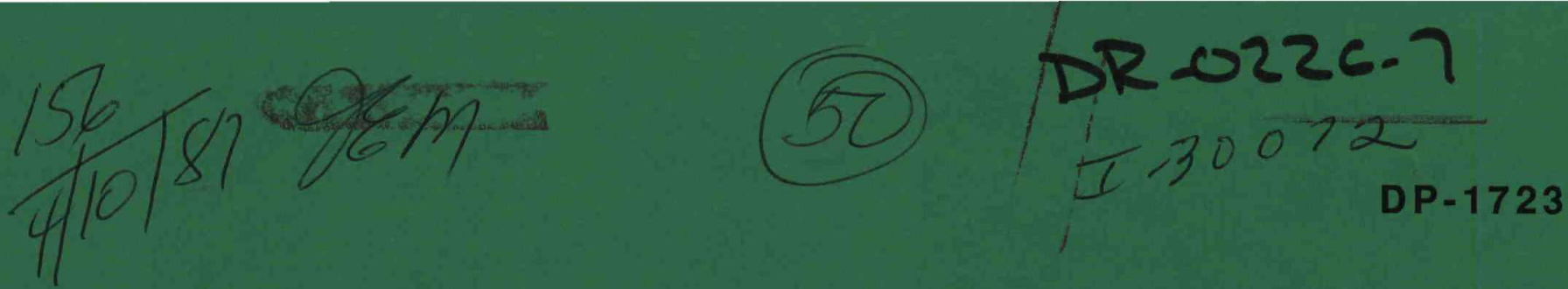

\title{
CERIUM OXALATE PRECIPITATION
}

T. P. CHANG

FEBRUARY 1987

DO NOT MICROFILM COVER

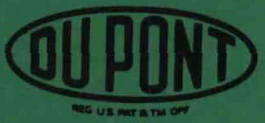

E. I. du Pont de Nemours \& Co. Savannah River Laboratory Aiken, SC 29808

PREPARED FOR THE U. S. DEPARTMENT OF ENERGY UNDER CONTRACT NO. DE-AC09-76SR00001 
This report was prepared by E. I. du Pont de Nemours and Company (Du Pont) for the United States Department of Energy under Contract DE-AC09-76SR00001 and is an account of work performed under that Contract. Neither the United States, the United States Department of Energy nor Du Pont, nor any of their employees, makes any warranty, express or implied, or assumes any legal liability or responsibility for the accuracy, completeness, or usefulness of any information, apparatus, product, or process disclosed herein, or represents that its use will not infringe privately owned rights. Reference herein to any specific commerical product, process, or service by trade name, mark, manufacturer, or otherwise does not necessarily constitute or imply endorsement, recommendation, or favoring of same by Du Pont or by the United States Government or any agency thereof. The views and opinions of authors expressed herein do not necessarily state or reflect those of the United States Government or any agency thereof.

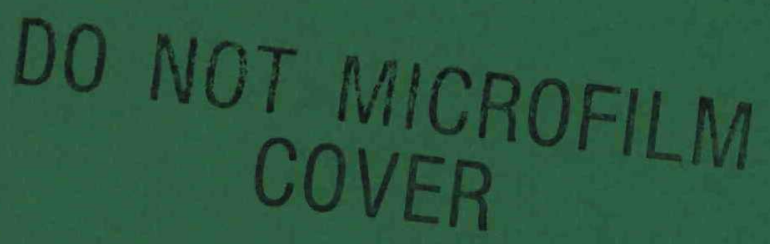




\section{DISCLAIMER}

This report was prepared as an account of work sponsored by an agency of the United States Government. Neither the United States Government nor any agency Thereof, nor any of their employees, makes any warranty, express or implied, or assumes any legal liability or responsibility for the accuracy, completeness, or usefulness of any information, apparatus, product, or process disclosed, or represents that its use would not infringe privately owned rights. Reference herein to any specific commercial product, process, or service by trade name, trademark, manufacturer, or otherwise does not necessarily constitute or imply its endorsement, recommendation, or favoring by the United States Government or any agency thereof. The views and opinions of authors expressed herein do not necessarily state or reflect those of the United States Government or any agency thereof. 


\section{DISCLAIMER}

Portions of this document may be illegible in electronic image products. Images are produced from the best available original document. 
DP.1723

Distribution Category: UC-4

Key Words

Cerium Oxalate

Precipitation

Crystallization

Nucleation

$\mathrm{DP}--1723$

\title{
CERIUM OXALATE PRECIPITATION
}

DE87 007832

\author{
DISCLAIMER
}

T. P. CHANG

Approved by:

R. J. Guschl, Research Manager

Actinide Technology Division

Publication Date: February 1987

\begin{abstract}
This report was prepared as an account of work sponsored by an agency of the United States Government. Neither the United States Government nor any agency thereof, nor any of their employees, makes any warranty, express or implied, or assumes any legal liability or responsibility for the accuracy, completeness, or usefulness of any information, apparatus, product, or process disclosed, or represents that its use would not infringe privately owned rights. Reference herein to any specific commercial product, process, or service by trade name, trademark, manufacturer, or otherwise does not necessarily constitute or imply its endorsement, recommendation, or favoring by the United States Government or any agency thereof. The views and opinions of authors expressed herein do not necessarily state or reflect those of the United States Government or any agency thereof.
\end{abstract}


Cerium, a nonradioactive, common stand-in for plutonium in development work, has been used to simulate several plutonium precipitation processes at the Savannah River Laboratory. There are similarities between the plutonium trifluoride and the cerium oxalate precipitations in particle size and extent of plating, but not particle morphology. The equilibrium solubility, precipitation kinetics, particle size, extent of plating, and dissolution characteristics of cerium oxalate have been investigated. Interpretations of particle size and plating based on precipitation kinetics (i.e. nucleation and crystal growth) are presented.

$-\mathrm{iii}-\mid N$ 
. 
Introduction

Background

Particle Size \& Precipitation Rinetics

2

Plating

Experimental Program

Solubility of Cerium Oxalate in Nitric Acid

Precipitation of Cerium Oxalate

6

Dissolution of Cerium Oxalate in Nitric Acid

6

10

Results and Discussion

Solubility Data

Nucleation \& Growth Rates, Particle Size

13

Plating

17

Dissolution

20

Conclusion

20

Acknowledgement

20

Nomenclature

22

References

23

$-v-\mid v i$ 



\section{ImrRoDuction}

At the Savannah River Plant (SRP), plutonium is currently precipitated from dilute nitrate solution with hydrofluoric acid (HF) to form plutonium trifluoride ( $\left.\mathrm{PuF}_{3}\right)$. Cerium, a common surrogate for $\mathrm{Pu}$, has been used often in the laboratory for scouting and development work, and in the plant for equipment functional testing. For instance, $C e$ was recently used for the "cold" functional testing of the new plant " $C$ " and "D" precipitators.

Several factors are considered in selecting plutonium surrogates for use in precipitation studies, e.g. similar chemistry, product characteristics (particle size, distribution, and morphology), and extent of plating. Cerium trifluoride $\left(\mathrm{CeF}_{3}\right)$ was first considered for simulating $\mathrm{PuF}_{3}$ because of the similar chemistry; e.g. one +3 cation reacts with three free fluoride $\left(F^{-}\right)$ ions. Laboratory studies found however, that $\mathrm{CeF}_{3}$ precipitations result in smaller particles due to their lower solubility and higher nucleation rates. In addition, the $\mathrm{CeF}_{3}$ particles produced during functional testing of plant precipitators were even smaller than those produced in the lab. Consequently, very long filtration times were experienced. Besides the slow filtration, very light (if any) plating was observed, which differed from the noticeable plating usually associated with $\mathrm{PuF}_{3}$ precipitation. Alternatives to the $\mathrm{CeF}_{3}$ flowsheet were sought to provide meaningful tests and to keep the functional testing on schedule.

Tests conducted in the laboratory indicated that cerium oxalate (CeOX) could replace $\mathrm{CeF}_{3}$ in simulating $\mathrm{PuF}_{3}$ because of similar mean particle sizes and plating characteristics. Plant tests later demonstrated that similar-size CeOX particles and slightly heavier plating were produced in the new plant precipitators than would have been expected with $\mathrm{PuF}_{3}$.

In general, precipitator performance is measured by three parameters: filtration time, filtrate losses, and extent of plating. All these parameters can be related (only qualitatively at the present time) to the equilibrium solubility data. The task of optimizing precipitator performance could be a much easier one if the relationship between precipitation kinetics and supersaturation (or equilibrium solubility) is well understood and can be correlated quantitatively. 
This report summarizes several fundamental properties of the cerium nitrate-oxalic acid--nitric acid system: solubility, nucleation rate, crystal growth rate, mean particle size, and plating characteristics. In addition, the rate of dissolution as a function of nitric acid concentration and temperature has been included. Our approach is to use this fundamental information to interpret phenomena observed during $1 \mathrm{ab}$ and full-scale experiments so that a better understanding of the precipitation mechanism can be achieved.

\section{BACRGROUID}

A two-stage precipitation system is currently used at the Savannah River Plant to precipitate $\mathrm{PuF}_{3}$, and a schematic diagram of this process is shown in Figure 1. Similar small-scale precipitators were set up in the laboratory for flowsheet optimization studies. Luerkens used both $\mathrm{Pu}$ and its surrogate, $\mathrm{Ce}$, in his twostage precipitation experiments.1,2 Figure 2 shows similar curves for the small-scale $\mathrm{PuF}_{3}$ and $\mathrm{CeF}_{3}$ mean particle size as a function of the first stage and "as mixed" hydrofluoric acid concentration ([HF $]_{a m}$ ). However, factors such as the quality of mixing (i.e. scale of segregation and intensity of segregation defined by Danckwerts ${ }^{3}$ ), degrees of agitation at each stage, and the degree of supersaturation in the second stage were left out in Luerkens' correlation. A brief discussion of the mixing and shear stress effect on particle size distribution in a precipitator can be found in Chang's report. 4

\section{Particle Size \& Precipitation Kinetics}

Particle size distribution is of great importance to many precipitation processes. Generally, the particle size distribution in a mixed suspension, mixed product removal (MSMPR) precipitator can be correlated by using the population balance equation, 5,6 which has two kinetics parameters: the nucleation rate (B), and the crystal growth rate (G). A simple population balance equation (Eq 1), proposed by Randolph and Larson, 4 was adopted for evaluating the nucleation and crystal growth rates of CeOX.

$$
\mathrm{dN} / \mathrm{dx}=\mathrm{n}=(\mathrm{B} / \mathrm{G}) * \exp (-\mathrm{x} /(G * \mathrm{t}))
$$

\footnotetext{
where $\mathbf{x}=$ characteristics crystal size (micron)

$\mathrm{N}=$ concentration of crystals smaller than $\mathrm{x}$ (非/vol)

$\mathrm{n}$ = population density of crystals of size $\times$ (\#//ol/micron)

$\mathrm{B}=$ nucleation $\mathrm{rate}$ (非/vol/min)

$G=$ crystal growth rate (micron/min)

$t=$ average residence time (min)
} 


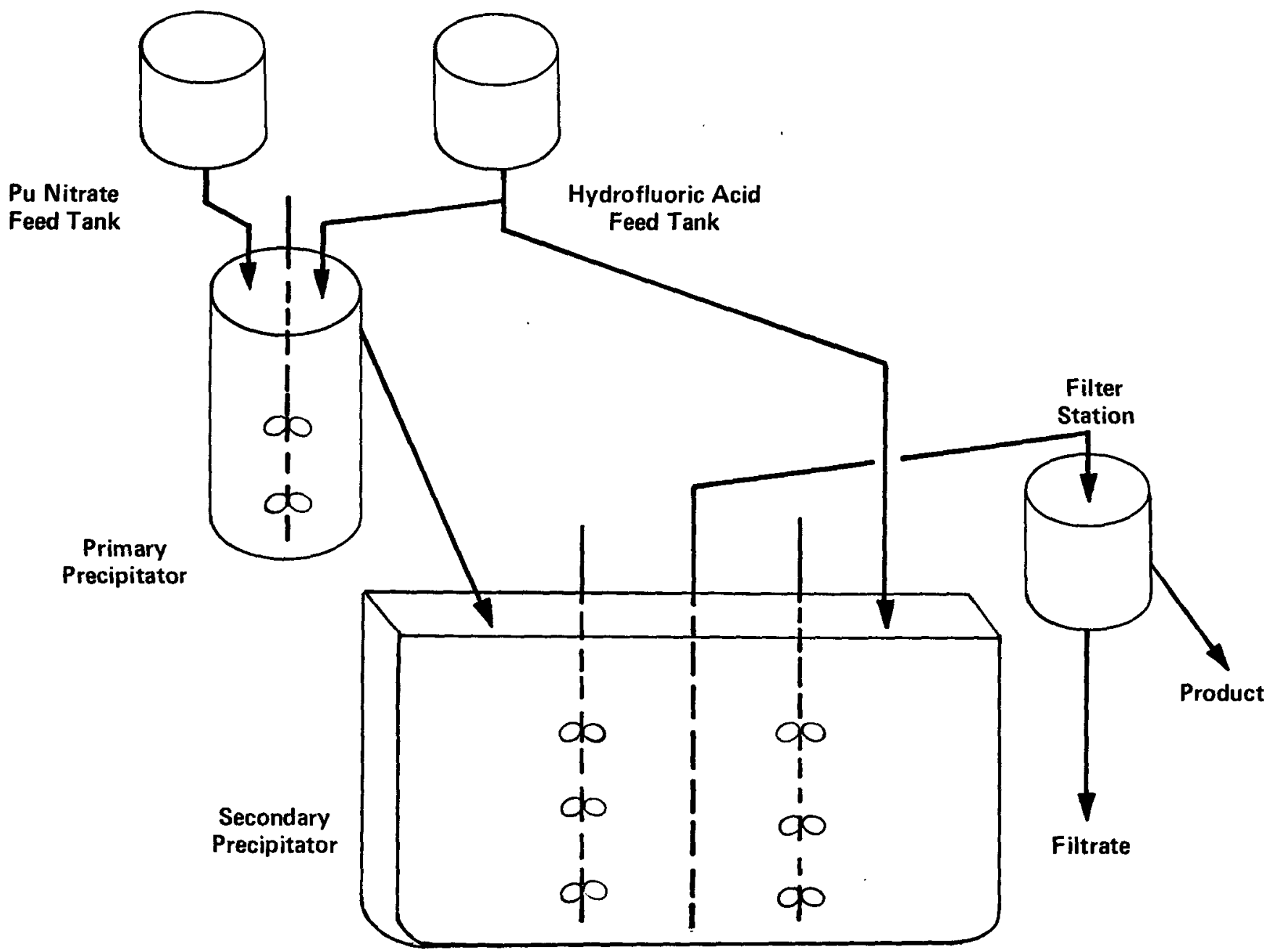

FIGURE 1. Two-stage PuF 3 Precipitation Process 


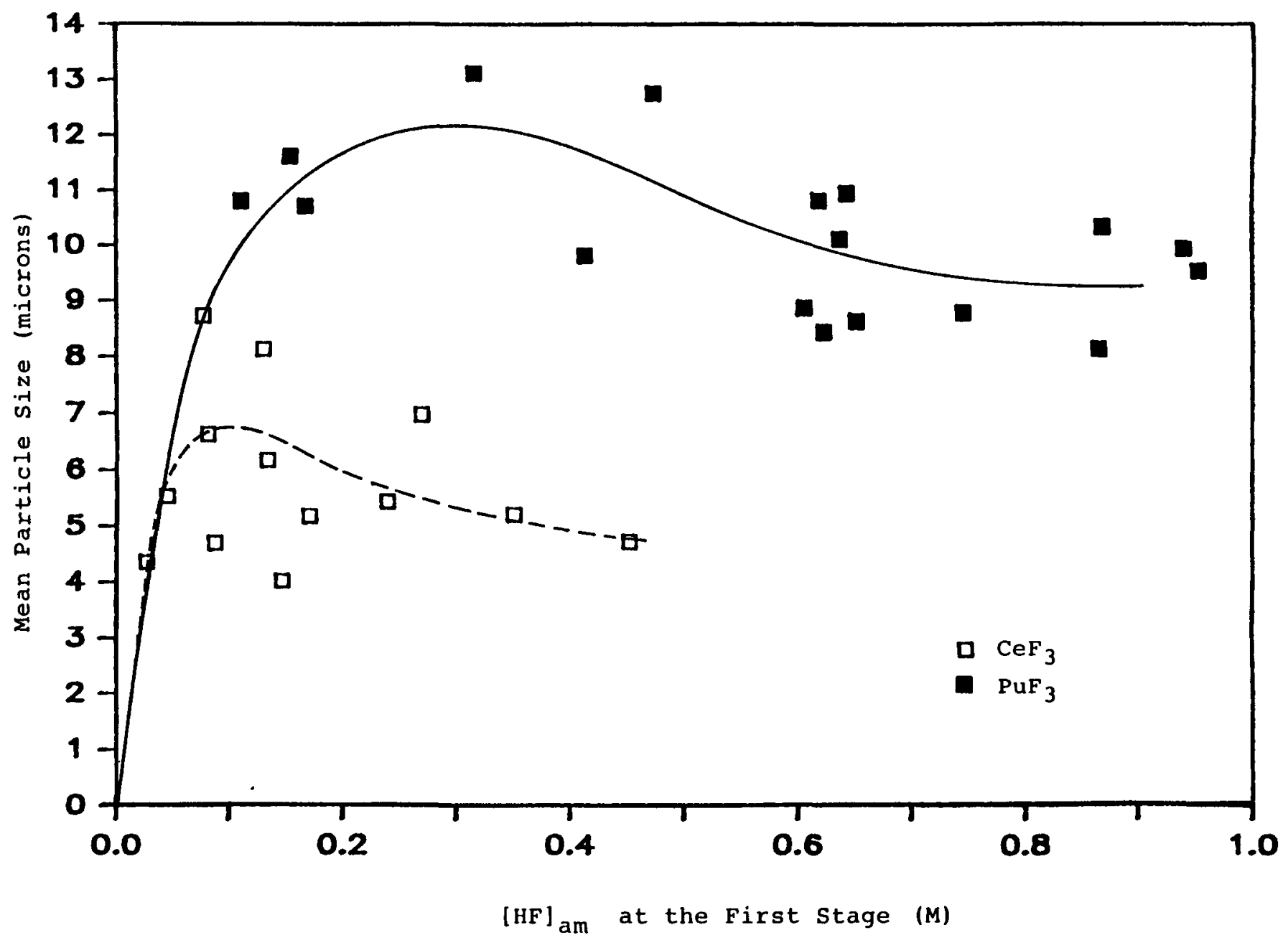

FIGURE 2. Second-Stage Particle size at Different First-Stage

"As-Mixed" Hydrofluoric Acid Concentrations, [HF] 1,2 
The nucleation rate is generally the dominating factor in influencing the precipitate's size distribution. Unfortunately, nucleation is the least understood, most difficult factor to describe by well-founded kinetic models. Because of the high supersaturation conditions for most precipitation processes, primary nucleation is expected to dominate. Walton ${ }^{7}$ proposed the following rate equation for primary nucleation.

$$
B=C_{1} * \exp \left[-C_{2} *^{3} /\left(T^{3} *(\ln (S))^{2}\right)\right]
$$

where $C_{1} \& C_{2}=$ characteristic constants

$\mathrm{r}=$ activity coefficient (dimensionless)
$\mathrm{T}=$ absolute temperature $\left({ }^{\circ} \mathrm{K}\right)$
$\mathrm{S}=$ supersaturation ration, conc/conceq (dimensionless)

This highly nonlinear rate equation is extremely difficult to measure because the nucleation process is followed immediately by the growth of newly formed nuclei before crystals can be detected by most instruments. The growth kinetics has been studied rather extensively for several crystallization processes.8,9,10 The growth rate, G, depends usually on the degree of supersaturation as well as temperature and crystal morphology. 11 Semiempirical nucleation and growth rate equations are expressed by Eq 3 and 4 .

$$
\begin{aligned}
& B=c_{b} * s^{b} \\
& G=c_{g} * s g
\end{aligned}
$$

where $C_{b} \& C_{g}=$ characteristic constants

$b \& g^{g}=$ power law coefficients

\title{
Plating
}

\begin{abstract}
Plating (or encrustation) is common in industrial crystallizers. Precipitates frequently deposit on the vessel surface, grow, and eventually flake off and block process lines. Plating is a serious problem for $\mathrm{PuF}_{3}$ precipitation because the $\alpha-N$ reaction from plated materials releases neutrons, which contribute to personnel radiation exposure.
\end{abstract}

Several parameters have been identified that could affect the extent of plating in a precipitation process. Most important is the surface finishing (i.e. smoothness) of the process vessel. 
Porter 12 reported that the extent of PuF plating varied from $25 \mathrm{mg} / 100 \mathrm{~cm}^{2}$ on a smooth platinum surface to $325 \mathrm{mg} / 100 \mathrm{~cm}^{2}$ on a rough molybdenum surface. Other factors such as the degree of supersaturation in precipitators, the ability of mixing reactants, and the capability of suspending slurries can also affect the extent of plating. In most cases, higher supersaturation (either due to overall or localized supersaturation) leads to heavier plating. Typically, localized supersaturation occurs more often in small precipitators and may be the main source of plating. Settling of large particles and inability to remove very fine particles from vessel surfaces are likely to be the cause of plating in many fullscale precipitators. Varying flow pattern can sometimes reduce plating. This is especially true when the wetted vessel surface is not smooth.

\section{EXPERIMIEMTAI PROGRAM}

The experimental program consisted of three parts: (1) A study of cerium oxalate solubility in the cerium nitrate-nitric acid--oxalic acid system was conducted; (2) A series of singlestage precipitations was performed to examine the filtration rate, particle size, and extend of plating of the CeOX flowsheet; (3) the dissolution of $\mathrm{CeOX}$ in various nitric acid concentrations and at different temperatures was examined.

\section{Solubility of Cerium Ozalate in Nitric Acid}

Different portions of cerium nitrate solution, distilled water, and nitric acid were mixed at room temperature $\left(22^{\circ} \mathrm{C}\right)$ in a $50 \mathrm{~mL}$ glass beaker agitated by a magnetic stirrer. Twenty-four runs were performed. Table 1 shows the amount of cerium nitrate, nitric acid, and oxalic acid added initially. Samples were left overnight then filtered. $\left[\mathrm{Ce}^{+3}\right],\left[\mathrm{H}^{+}\right]$, and total oxalate [OX] analyses were made on the filtrate samples.

\section{Precipitation of Cerium Oxalate}

The Pu-surrogate feed $(0.12 \mathrm{M}$ cerium nitrate in $1.5 \mathrm{M}$ nitric acid) and the precipitant feed $(0.8 \mathrm{M}$ oxalic acid) were added simultaneously to single-stage, lab-scale precipitators. A 3/4" marine propeller, rotated between 600 and 750 RPM, provided exce1lent mixing. Two polypropylene (PP) beakers from different vendors were used for evaluating the plating characteristics. One beaker, by Nalgene, had a smoother surface than the other one, by American Scientific Products (Figure 3). Constant liquid volume in the precipitator $(75 \mathrm{~mL})$ was maintained by utilizing an overflow line. Experimental conditions such as the feed rates and concentrations are listed in Table 2. The particle population density and mean 


\section{TABLE 1}

Test Conditions for Cerium Oxalate Bquilibrium Experiment

\begin{tabular}{|c|c|c|c|c|}
\hline Test & {$\left[\mathrm{Ce}^{+3}\right](\mathrm{mL})$} & {$\left[\mathrm{HNO}_{3}\right](\mathrm{mL})$} & {$\left[\mathrm{H}_{2} \mathrm{O}\right](\mathrm{mL})$} & [Oxalic Acid] \\
\hline E01 & 0.541 & 3.872 & 15.587 & 1.70 \\
\hline E02 & 0.541 & 3.872 & 15.587 & 2.36 \\
\hline E0 3 & 0.541 & 3.872 & 15.587 & 3.00 \\
\hline E04 & 0.541 & 3.872 & 15.587 & 4.20 \\
\hline E05 & 1.840 & 3.752 & 14.408 & 1.70 \\
\hline E06 & 1.840 & 3.752 & 14.408 & 3.00 \\
\hline E07 & 1.840 & 3.752 & 14.408 & 4.20 \\
\hline E08 & 1.840 & 3.752 & 14.408 & 5.20 \\
\hline E09 & 3.623 & 3.588 & 12.789 & 3.00 \\
\hline E10 & 3.623 & 3.588 & 12.789 & 4.20 \\
\hline El 1 & 3.623 & 3.588 & 12.789 & 5.20 \\
\hline E12 & 3.623 & 3.588 & 12.789 & 6.20 \\
\hline E13 & 0.541 & 7.795 & 11.664 & 8.20 \\
\hline E14 & 0.541 & 7.795 & 11.664 & 10.40 \\
\hline E15 & 0.541 & 7.795 & 11.664 & 12.40 \\
\hline E16 & 0.541 & 7.795 & 11.664 & 15.60 \\
\hline E17 & 1.840 & 7.675 & 10.485 & 8.20 \\
\hline E18 & 1.840 & 7.675 & 10.485 & 12.40 \\
\hline E19 & 1.840 & 7.675 & 10.485 & 15.60 \\
\hline E20 & 1.840 & 7.675 & 10.485 & 18.40 \\
\hline E2 1 & 3.623 & 7.510 & 8.867 & 12.40 \\
\hline E22 & 3.623 & 7.510 & 8.867 & 15.60 \\
\hline E23 & 3.623 & 7.510 & 8.867 & 18.40 \\
\hline E24 & 3.623 & 7.510 & 8.867 & 20.00 \\
\hline
\end{tabular}

Concentrations of Stock Solutions:

Cerium Nitrate: $\left[\mathrm{Ce}^{+3}\right]=0.462 \mathrm{~m} ;\left[\mathrm{H}^{+-}\right]=0.471 \mathrm{M}$ Nitric Acid: $\quad\left[\mathrm{H}^{+}\right]=5.099 \mathrm{M}$

Oxalic Acid $\quad\left[H^{+}\right)=2.02 \mathrm{M}$; [OX] $=1.07 \mathrm{~m}$ 


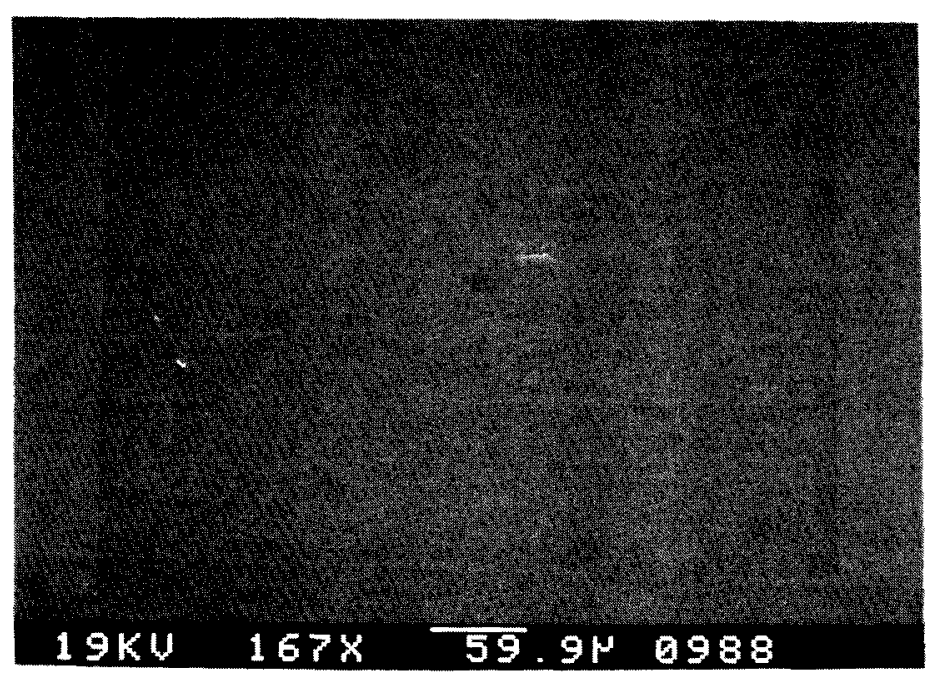

(3a) New Nalgene Beaker

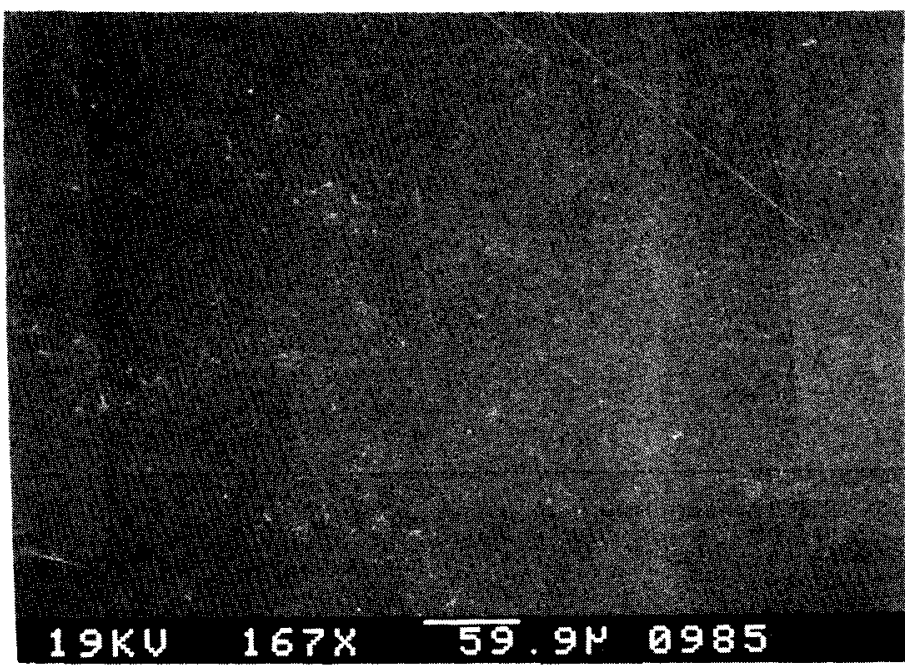

(3c) Used Nalgene Beaker

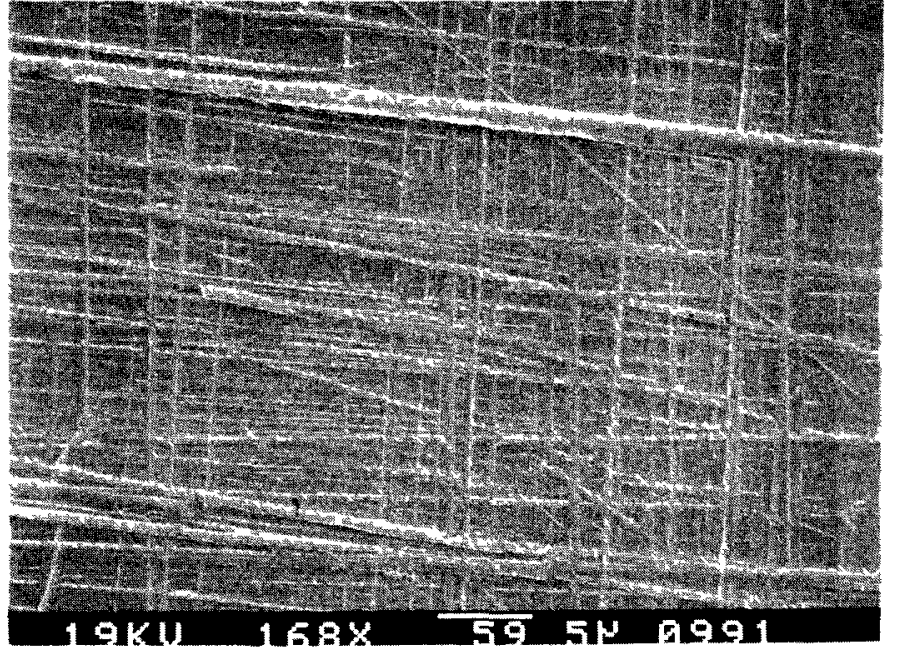

(3b) New ASP Beaker

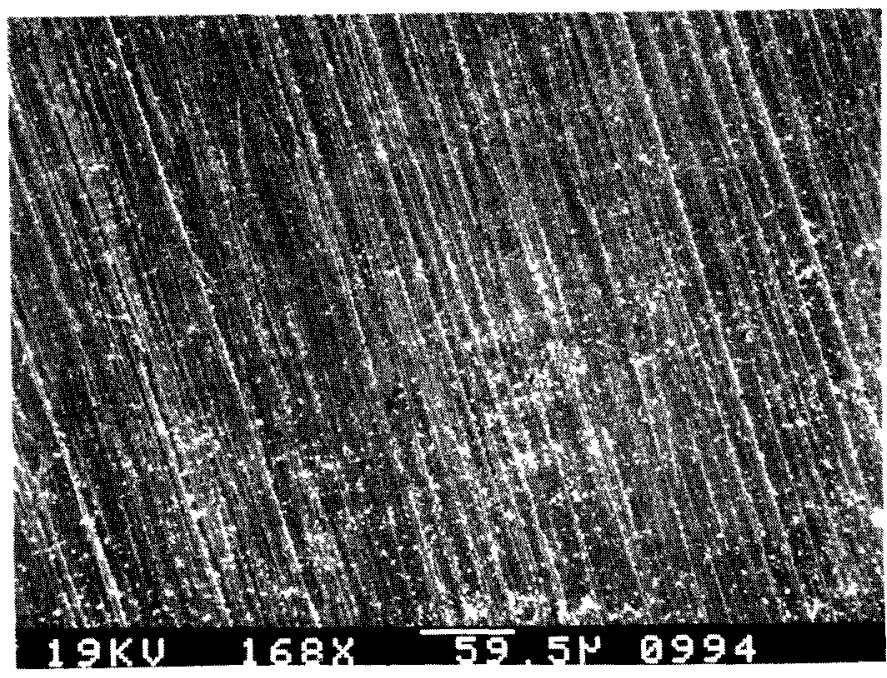

(3d) Used ASP Beaker

FIGURE 3. Surfaces of Nalgene and American Scientific Product (ASP) Beakers: 3a 3b Before Precipitation, $3 c \& 3 d$ Rinsed with Hot Water after Precipitation 
TABLE 2

Test Condition and Performance for Ceriun Oxalate Precipitation

\begin{tabular}{|c|c|c|c|c|c|c|c|c|}
\hline Test & $\begin{array}{l}\text { Feed R } \\
(\mathrm{mL} / \mathrm{mi} \\
{\left[\mathrm{Ce}^{+3}\right]}\end{array}$ & [0X] & $\begin{array}{l}\text { Feed C } \\
(\mathrm{M}) \\
{\left[\mathrm{Ce}^{+3}\right]}\end{array}$ & [OX] & Beakers & $\begin{array}{l}\text { Particle } \\
\text { Man Size } \\
\text { (microns) }\end{array}$ & $\begin{array}{l}\text { Extent of } \\
\text { Plating } \\
\left.\text { (mg/100 } \mathrm{cm}^{2}\right)\end{array}$ & $\begin{array}{l}\text { Relative } \\
\text { Filtr. } \\
\text { Rate* }\end{array}$ \\
\hline P01 & 8.0 & 5.0 & 0.12 & 0.8 & Nalgene & $\mathrm{N} / \mathrm{A}$ & 180 & 1.60 \\
\hline P02 & 8.0 & 4.0 & 0.12 & 0.8 & Nalgene & 21.1 & 150 & 1.97 \\
\hline P03 & 8.0 & 3.0 & 0.12 & 0.8 & Nalgene & 25.9 & 180 & 2.19 \\
\hline P04 & 8.0 & 1.0 & 0.12 & 0.8 & Nalgene & 20.2 & 270 & 1.74 \\
\hline P05 & 7.5 & 3.6 & 0.12 & 0.8 & ASP & 25.2 & 1110 & 1.77 \\
\hline P06 & 8.0 & 3.0 & 0.12 & 0.8 & ASP & 30.1 & 880 & 2.28 \\
\hline P07 & 8.0 & 2.0 & 0.12 & 0.8 & ASP & 22.6 & 790 & 1.64 \\
\hline P08 & 8.0 & 1.0 & 0.12 & 0.8 & ASP & 29.9 & 390 & 3.28 \\
\hline P09 & 8.0 & 0.5 & 0.12 & 0.8 & ASP & 26.4 & 260 & 2.31 \\
\hline P10 & 4.0 & 1.0 & 0.12 & 0.8 & ASP & 29.4 & 400 & 2.28 \\
\hline P11 & 8.0 & 5.0 & 0.12 & 0.7 & ASP & N/A & 770 & 1.89 \\
\hline P12 & 8.0 & 3.0 & 0.12 & 0.7 & ASP & N/A & 670 & 2.62 \\
\hline
\end{tabular}

The relative filtration rate is the ratio of times required to filter the same volume of cerium oxalate and distilled water, i.e. the higher the value the slower the filtration rate. 
particle size were measured by a Coulter Counter ${ }^{\oplus}$. The extent of plating was the weight gained by a precipitator during 60 minutes of precipitation. Particle morphology was examined by a scanning electron microscope (SEM).

\section{Dissolution of Cerium Oxalate in Nitric Acid}

The dissolution study of Ceox in nitric acid consisted of two parts. The first set of runs was conducted at room temperature $\left(22^{\circ} \mathrm{C}\right)$, the second set at $50^{\circ} \mathrm{C}$. Dissolution rates of CeOX in various nitric acid concentrations $(3,6,8,12$, and $16 \mathrm{M})$ were also investigated. Each sample ( $1.5 \mathrm{~g}$ of CeOX crystals) was mixed with $20 \mathrm{~mL}$ nitric acid of various concentrations with occasional agitation. The time needed to dissolve all solids was recorded.

\section{RESULTS AND DISCUSSIOR}

\section{Solubility Data}

Both kinetic parameters $B$ and $G$ are dependent variables of the equilibrium solubility as shown by Eq $1,2,3$, and 4 . As a result, the particle size and size distribution will be affected by the degree of supersaturation during precipitations. Solubility data for $\mathrm{PuF}_{3}, \mathrm{Pu}$ (III) oxalate, and $\mathrm{CeF}_{3} \mathrm{can}$ be found in the works of Burney and Tober, 13 Burney and Porter, 14 and Luerkens ${ }^{2}$ respective1y. CeOX solubility at room temperature was measured in this study. Table 3 shows the analytical results of $\left[\mathrm{Ce}^{+3}\right],\left[\mathrm{H}^{+}\right]$, and [OX] in the filtrate. As expected, cerium concentration in the filtrate increases as the nitric acid concentration increases, and decreases as the oxalate concentration decreases. The solubility relationship fitted by a nonlinear regression routine is expressed by Eq 5 and shown in Figure 4 .

$$
\left[\mathrm{Ce}^{+3}\right]=0.763 *\left[\mathrm{H}^{+}\right]^{3.334} /[\mathrm{OX}]^{1.717}
$$

where $\left[\mathrm{Ce}^{+3}\right]=$ cerium concentration in the filtrate (mg/liter)

$\left[\mathrm{H}^{+}\right]=$total acid in the filtrate (M)

$[0 X]=$ total oxalate concentration in the filtrate $(M)$

We also can derive this solubility relationship from the solubility product constant $15\left(\mathrm{~K}_{\mathbf{8 p}}\right)$ and the dissociation constants of oxalic acidl5 $\left(K_{1}, K_{2}\right)$. As suming the filtrate solution is ideal (i.e. activity coefficient is equal to 1 ), the cerium concentration in the filtrate can be calculated from Eq 6 .

$$
\left[\mathrm{Ce}^{+3}\right]=\mathrm{C}_{3} *\left[\mathrm{H}^{+}\right]^{3.0} /[\mathrm{OX}]^{1.5}
$$


TABLE 3

Cerium Oxalate Equilibrium Solubility Data

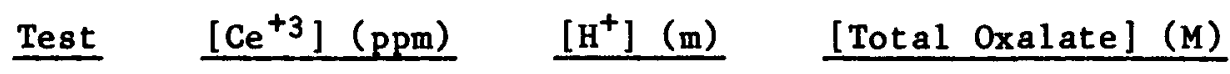

\begin{tabular}{|c|c|c|c|c|}
\hline E01 1 & 112.0 & 1.050 & 5.57 & E-02 \\
\hline E02 & 61.0 & 1.082 & 8.00 & E-02 \\
\hline E0 3 & 37.6 & 1.097 & 1.074 & E-01 \\
\hline E04 & 20.8 & 1.146 & 1.514 & $E-01$ \\
\hline E0 5 & 757.6 & 1.039 & 1.98 & $\mathrm{E}-02$ \\
\hline E06 & 94.1 & 1.084 & 6.58 & $\mathrm{E}-02$ \\
\hline E0 7 & 41.8 & 1.143 & 1.091 & E-01 \\
\hline E08 & 29.4 & 1.138 & 1.428 & $E-01$ \\
\hline E09 & 1049.0 & 1.133 & 1.88 & $\mathrm{E}-02$ \\
\hline E 10 & 194.0 & 1.129 & 5.19 & $E-02$ \\
\hline E11 & 80.5 & 1.155 & 8.44 & $\mathrm{E}-02$ \\
\hline E12 & 46.9 & 1.188 & 1.195 & $E-01$ \\
\hline E1 3 & 63.3 & 1.964 & 2.911 & $E-01$ \\
\hline E14 & 43.1 & 1.964 & 3.434 & $E-01$ \\
\hline E15 & 39.8 & 2.125 & 4.127 & $\mathrm{E}-01$ \\
\hline E16 & 28.3 & 1.964 & 4.501 & $\mathrm{E}-01$ \\
\hline E17 & 86.2 & 1.942 & 2.474 & $E-01$ \\
\hline E18 & 40.4 & 1.931 & 3.557 & $E-01$ \\
\hline E19 & 29.8 & 1.930 & 4.163 & $E-01$ \\
\hline E20 & 24.9 & 1.911 & 4.635 & $E-01$ \\
\hline E2 1 & 73.7 & 1.941 & 3.170 & $E-01$ \\
\hline E22 & 50.7 & 1.984 & 3.790 & $E-01$ \\
\hline E23 & 32.9 & 1.955 & 4.343 & E-01 \\
\hline E24 & 34.0 & 1.937 & 4.624 & $E-01$ \\
\hline
\end{tabular}




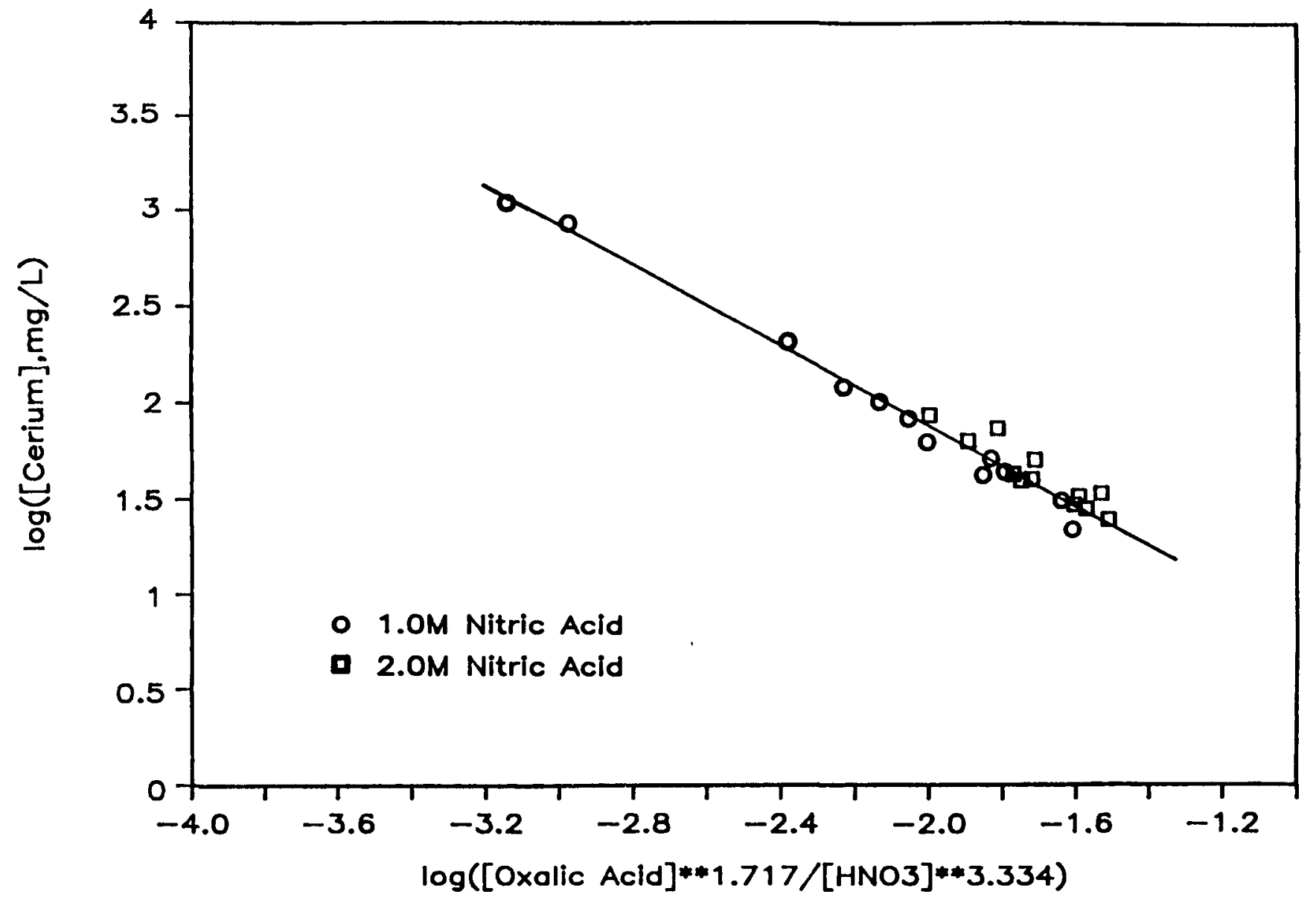

F1GURE 4. Solubility of Cerium Oxalate in Nitric/Oxalic Acids 
where $\mathrm{C}_{3}=\mathrm{M}_{\mathrm{Ce}} * 1000 \mathrm{mg} / \mathrm{g} *\left(\mathrm{~K}_{\mathrm{sp}} /\left(\mathrm{K}_{1} * \mathrm{~K}_{2}\right)^{3}\right) .5,0.155$

$\mathrm{M}_{\mathrm{Ce}}=$ molecular weight of cerium ( $\left./ \mathrm{mole}\right), 140$

$\mathrm{K}_{\mathrm{sp}}=$ solubility product constant of CeOX, $3.0 \mathrm{E}-29$

$\mathrm{K}_{\mathrm{l}}=$ first dissociation constant of oxalic acid, $5.36 \mathrm{E}-2$

$\mathrm{K}_{2}=$ second dissociation constant of oxalic acid, $5.42 \mathrm{E}-5$

Equations 5 and 6 agree well. The constant term is 0.763 in Eq 5 and 0.155 in Eq 6 . The deviation is probably due to nonideal solution behaviors.

\section{Nucleation \& Growth Rates, Particle Size}

Because our precipitator was operated under the MSMPR mode, the nucleation and growth rates can be obtained by plotting the natural logarithm ( $1 n$ ) of the population density, $n$, versus the crystal size, $x$. According to $\mathrm{Eq} 1$, a straight 1 ine should result. The growth rate is determined from the slope of the curve $\left(-1 /\left(g^{*} t\right)\right)$ and the residence time $(t)$. The nucleation $r$ ate is determined from the growth rate and the intercept $(B / G)$.

Table 4 lists the population density data from one cerium oxalate precipitation (Run P02, Table 2) with as-mixed cerium and oxalic concentrations of $0.08 \mathrm{M}$ and $0.27 \mathrm{M}$ respectively in $1 \mathrm{M}$ nitric acid solution. The nucleation rate is $2.01 \mathrm{E} 11 \mathrm{nuclei} / \mathrm{m}^{3} / \mathrm{minute}$ and the growth rate is $2.6 \mathrm{microns} / \mathrm{minute}$. The population density plot is shown in Figure 5 and it is not a straight line. (The growth rate of $2.6 \mathrm{microns} / \mathrm{minute}$ was determined by fitting data with a least-squares routine assuming constant G.) The smaller "absolute" slope (faster growth rate) for larger particles could mean that small crystals are being dissolved to provide nutrients for already-formed large crystals to grow further when the latter is thermodynamically favorable (the ripening effect ${ }^{16}$ ). This superficial faster growth rate for large crystals could also be the result of aggregation of small crystals. Size-dependent growth (e.g. 1 and $2.7 \mathrm{microns} / \mathrm{min}$ for crystals smaller and larger than 28.7 microns respectively) is another possibility. More extensive studies are needed to verify the relationships described by Eq 3 and 4 and to quantify the parameters.

The kinetic rates for $\mathrm{PuF}_{3}$ and $\mathrm{CeF}_{3}$, as shown in Table 5, are derived from Luerkens' experimental results.1,2 CeF 3 exhibits the smallest mean size because of its higher supersaturation ratio, $S$, the fastest nucleation rate (B) and the slowest growth rate (G). Both $B$ and $G$ are related to $\mathrm{S}$. $\mathrm{PuF}_{3}$ and $\mathrm{CeOX}$ have very different $\mathrm{B}$ but similar $S$ and more comparable mean particle size. 
TABLE 4

Population Density Data of Run \$PO2

\begin{tabular}{|c|c|c|}
\hline $\begin{array}{l}\text { Particle Size } \\
\text { (micron) } x \\
\end{array}$ & $\begin{array}{l}\text { Population Density } \\
\left(\# / m i c r o n / M^{3}\right) \mathrm{n}\end{array}$ & $\ln (n)$ \\
\hline 11.4 & 1.179 E11 & 25.49 \\
\hline 14.4 & 5.918 E10 & 24.80 \\
\hline 18.1 & 3.005 E10 & 24.13 \\
\hline 22.8 & $1.503 \mathrm{E} 10$ & 23.43 \\
\hline 28.7 & 7.353 E09 & 22.72 \\
\hline 36.2 & 4.064 E09 & 22.13 \\
\hline 45.5 & 2.443 E09 & 21.62 \\
\hline 57.4 & 1.312 E09 & 21.00 \\
\hline 7.23 & 6.764 E08 & 20.33 \\
\hline 91.1 & 2.184 E08 & 19.20 \\
\hline 114.8 & $5.852 \mathrm{E} 07$ & 17.88 \\
\hline 144.5 & $1.253 \mathrm{E} 07$ & 16.34 \\
\hline 182.0 & 8.689 EO5 & 13.68 \\
\hline
\end{tabular}




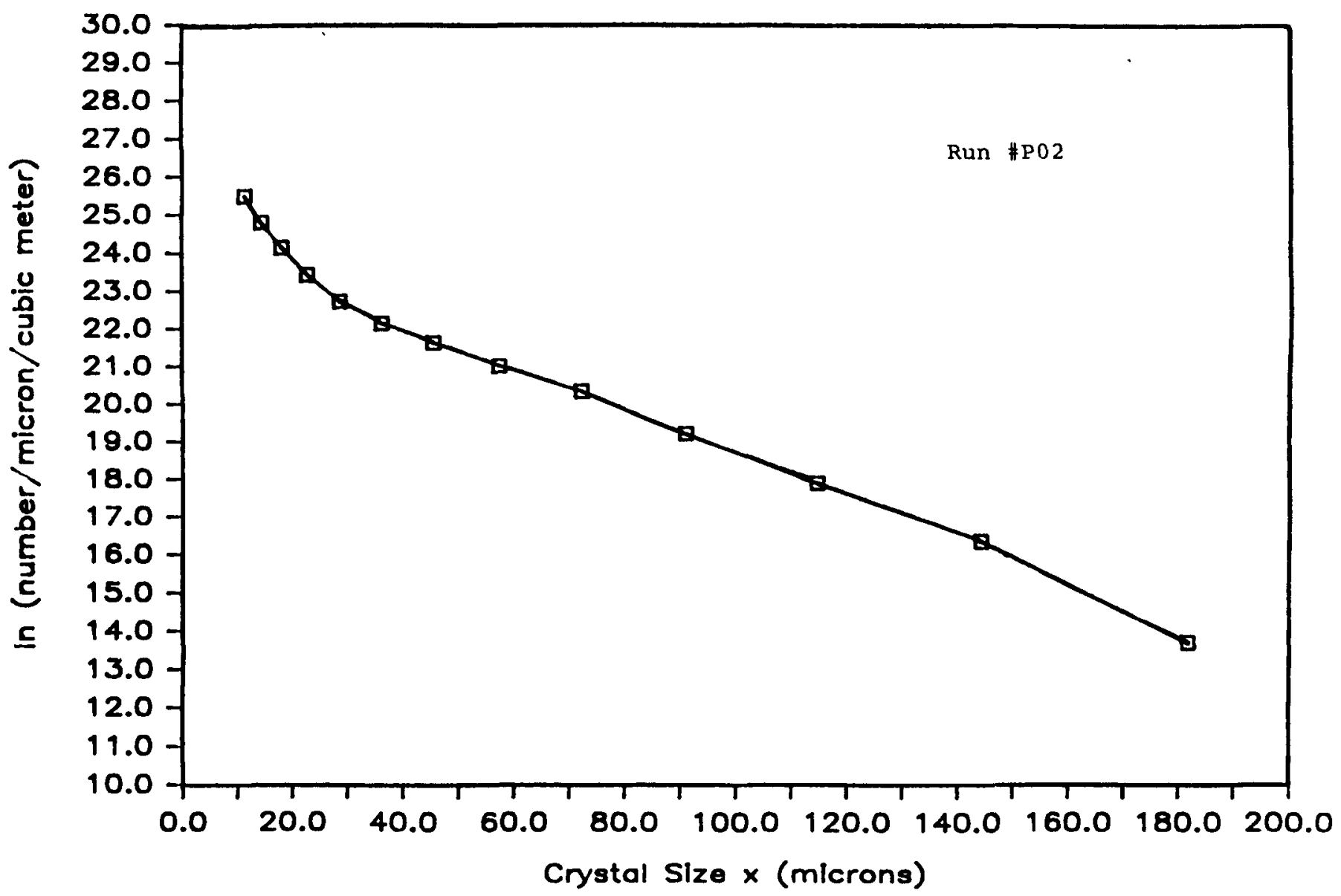

FIGURE 5. Population Density Plot of Cerium Oxalate from an MSMPR Precipitator 


\section{TABLE 5}

Rinetic Rates, Supersaturation Ratio, and Particle size for Laboratory $\mathrm{PuF}_{3}, \mathrm{CeF}_{3}$, and CeOX Precipitations

\begin{tabular}{|c|c|c|c|c|c|c|}
\hline \multirow[b]{2}{*}{$\mathrm{PuF}_{3}$} & \multicolumn{2}{|c|}{$\begin{array}{l}\text { Nucleation Rate, B } \\
\left(\# / \mathrm{M}^{3} / \mathrm{min}\right)\end{array}$} & \multirow{2}{*}{$\begin{array}{l}\begin{array}{l}\text { Growth Rate, G } \\
\text { (micron/min) }\end{array} \\
1.02\end{array}$} & \multicolumn{2}{|c|}{$\begin{array}{l}\text { Supersaturation } \\
\text { Ratio }\left(c / c_{e q}\right)\end{array}$} & \multirow{2}{*}{$\frac{\begin{array}{l}\text { Mean Size } \\
\text { (microns) }\end{array}}{13.1}$} \\
\hline & 1.72 & E13 & & 1.96 & E3 & \\
\hline $\mathrm{CeF}_{3}$ & 4.09 & E13 & 0.41 & 3.71 & E5 & 4.2 \\
\hline CeOX & 2.01 & E11 & 2.64 & 1.56 & E3 & 21.1 \\
\hline
\end{tabular}

Derived from Luerkens' $\mathrm{PuF}_{3}$ data, DP-1680 l Run \#4, Derived from Luerkens' $\mathrm{CeF}_{3}^{3}$ data, DP-16842 Run \#10, CeOX data from this work Run \#P02 
As shown in Table 3, the mean particle size of CeOX precipitates ranges from 20 to 30 microns over a wide nitric acid/oxalic acid ration ( $R$ ). Past experience with $\mathrm{CeF}_{3}$ precipitation suggested that much smaller CeOX particles might be produced in a full-scale precipitator. One full-scale run was then performed in the laboratory. The CeOX mean particle size was around 13 microns, which was close to the size of PuF 3 particles produced inplant (10-15 microns). Subsequently, five plant runs in the new " $D$ " precipitator produced mean size particles of $11.2,13.6,14.4,14.7$, and 13.2 microns, which agreed extremely well with the 1 ab results.

Scanning electron microscope pictures were also obtained for routine morphology analyses. As shown in Figure 6, CeOX morphology is distinctly different from that of $\mathrm{PuF}_{3}$ and similar to that of plutonium oxalate $(P u O X)$. In this test work, we did not try to vary the flowsheet to examine its effect on the product morphology.

\section{Plating}

The extent of plating at various supersaturation levels is listed in Table 2. Results also show that different trends exist between precipitators with smooth and less-smooth surface finishes. This is illustrated in Figure 7. The extent of plating is very sensitive to the acid ratio $R\left(\left[\mathrm{HNO}_{3}\right]_{a m} /\left[\mathrm{H}_{2} \mathrm{C}_{2} \mathrm{O}_{4}\right]_{a m}\right)$ in the rougher American Scientific Products beaker. However, the extent of plating in the smoother Nalgene beaker is not a strong function of $R$ between the range of 3 to 30 . Plating even decreases slightly in the smooth Nalgene beaker at small values of $R$.

It is likely that the plating on a less-smooth surface starts when newly formed nuclei are trapped on the rough surface (viewing from nuclei). More nuclei are formed at a smaller $R$, and more are trapped, hence more severe plating. On the other hand, it is difficult to trap nuclei and particles on a smooth surface. As excess oxalic acid increases (i.e. smaller $R$ ), the nucleation becomes the predominant step, which not only produces a large amount of fines, but also depleted cerium and oxalate rapidly. Because fewer particles are trapped on the smooth surface and because the supernatant condition no longer favors crystal growth, less plating is observed. At a larger $R$ (i.e. lower supersaturation), nucleation rate reduces, fewer nuclei are produced, and a pro-growth environment is established because more nutrients are available. When the rate of deposition surpasses the rate of growth, more plated material will be seen. This probably explains why more plating is observed on a smooth surface at smaller values of $R$. In the plant large-scale precipitators, plating is sometimes caused by poor slurry suspension. Settling of large particles and inability to remove small particles from vessel surfaces have contributed significantly to the plating in large-scale slab precipitators. 


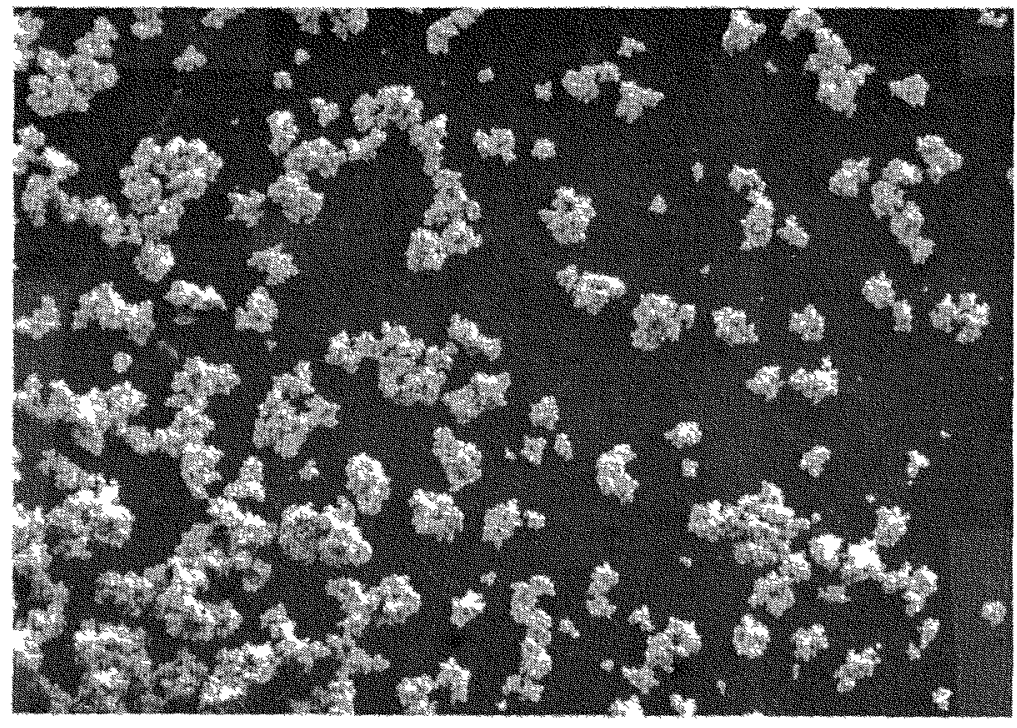

$\mathrm{PuF}_{3}$ (100X) $\infty$

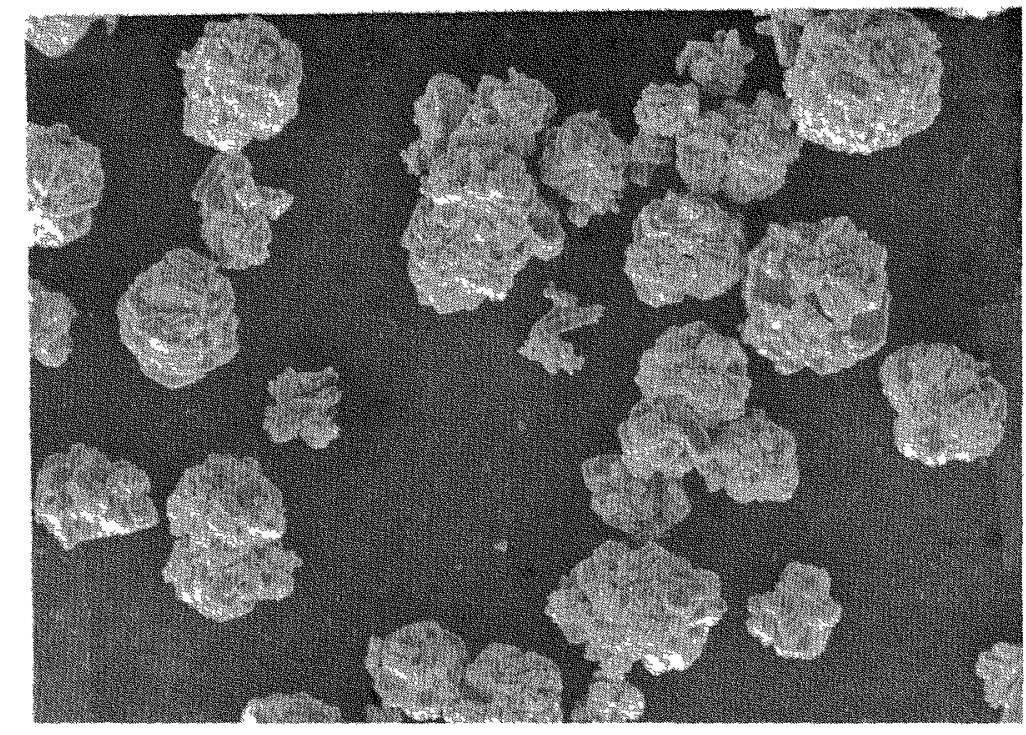

Pu Oxalate (100x)

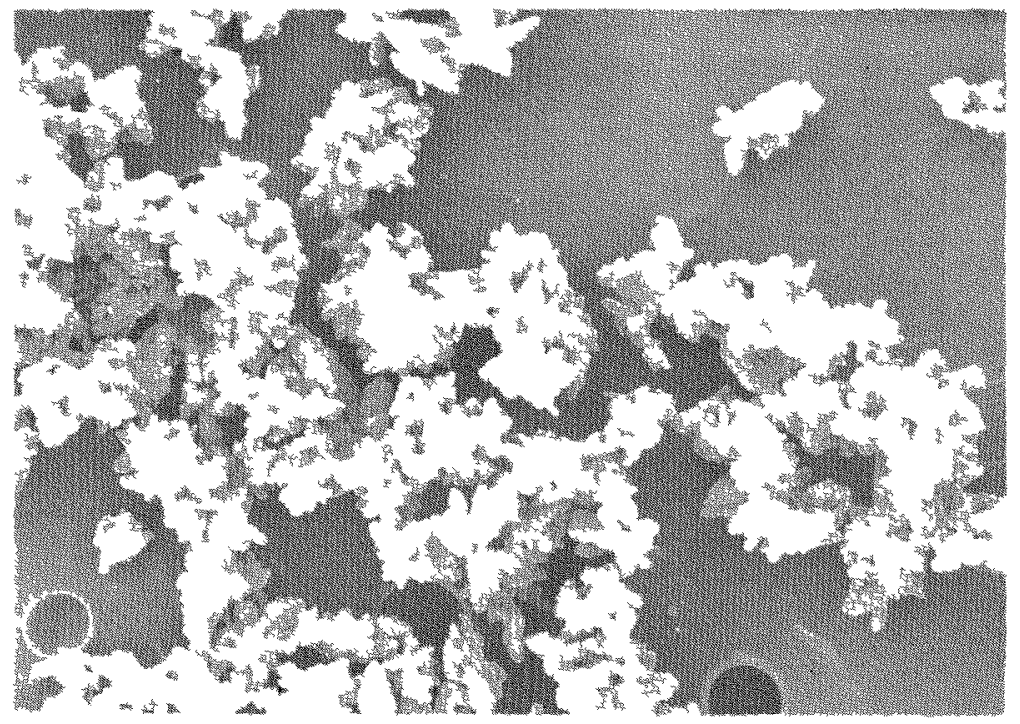

Ce Oxalate (100x)

FIGURE 6. SEM Pictures of Cerium, Plutonium Oxalates and Trifluoride 


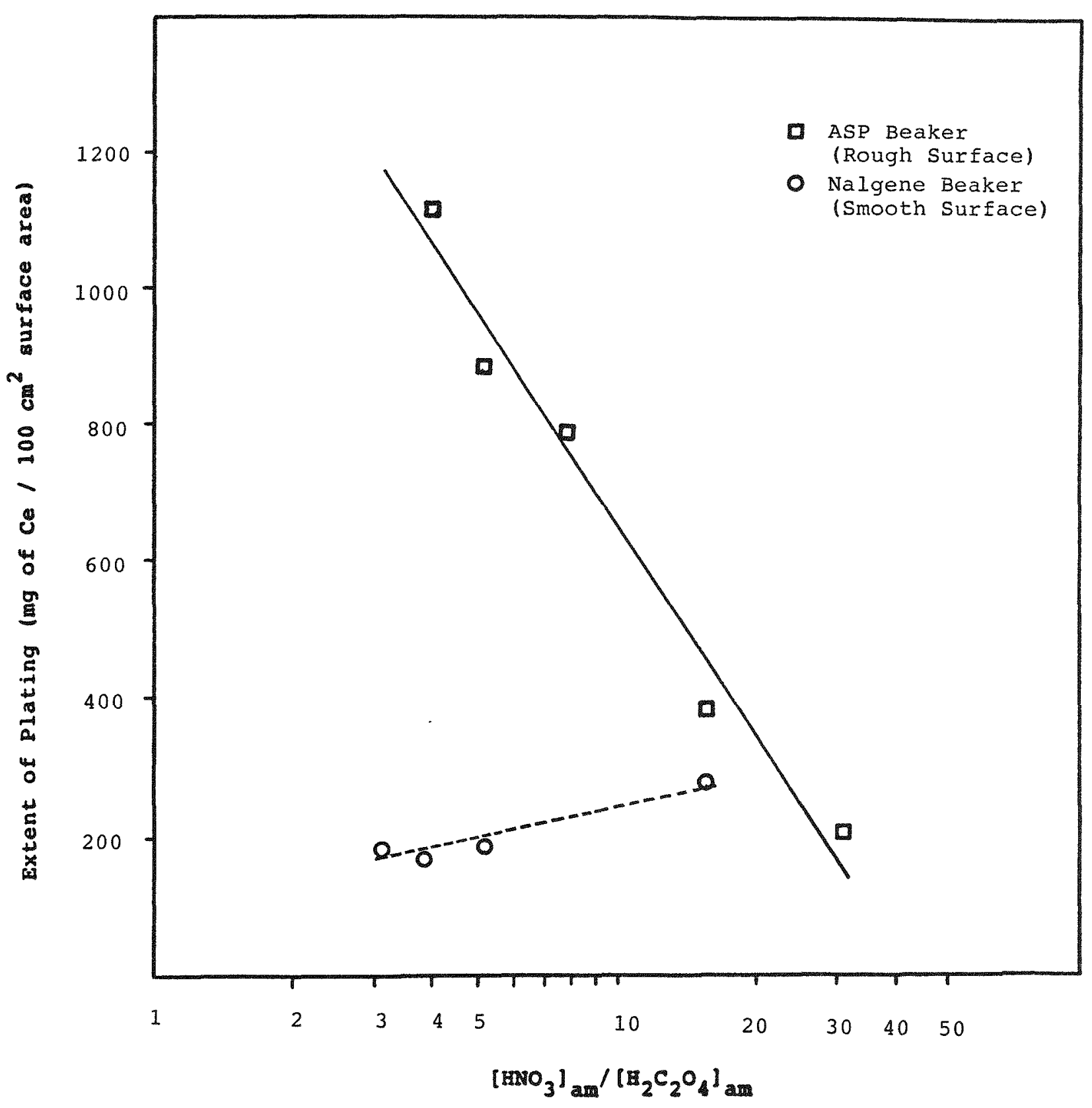

FIGURE 7. Extent of Cerium Oxalate Plating on Two Types Precipitator as a Function of $\mathrm{HNO}_{3} \mathrm{H}_{2} \mathrm{C}_{2} \mathrm{O}_{4}$ Ratio (R) 


\section{Dissolution}

Laboratory experiments showed that cerium oxalate dissolved easily in moderate $(6-8 \mathrm{M})$ and higher concentrations of nitric acid. Dissolution was much faster when the samples were heated to $50^{\circ} \mathrm{C}$. Observations from this dissolution study are summarized in Table 6 . Crystallization was observed in the 6M nitric acid solution after it was diluted with $10 \mathrm{~mL}$ distilled water and cooled overnight. Lower solubility at a lower temperature probably caused the recrystallization. The plant used $8 M$ nitric acid during cleanout runs of new " $C$ " and "D" precipitators and encountered no problems.

\section{COICLUSIOI}

Switching from $\mathrm{CeF}_{3}$ to cerium oxalate during the functional checkout of the new "D" precipitator proved to be very successful. Particle size and plating similar to the PuF 3 process were achieved. The filtration time was reduced to $15-25$ minutes, which was far shorter than the 4-8 hours with $\mathrm{CeF}_{3}$. In addition, cerium oxalate in the system was flushed out easily and quickly with warm

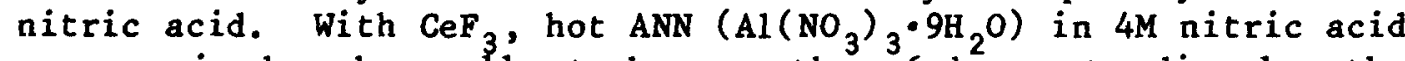
was required and usually took more than 6 hours to dissolve the plated $\mathrm{CeF}_{3}$. A valid evaluation of the mixing and suspension capabilities of the new " $D$ " precipitator was accomplished because of the similar particle size and settling velocity between $\mathrm{PuF}_{3}$ and Ceox. Fast filtration and rapid removal of the CeOX also enabled the testing program to be kept on schedule. Overall, cerium oxalate was a better stand-in than the $\mathrm{CeF}_{3}$ for the simulation of $\mathrm{PuF}_{3}$ precipitation.

The measurement of fundamental properties of the cerium nitrate - nitric acid - oxalic acid system has allowed a better understanding of precipitation mechanisms and characteristics. A different approach, which utilizes kinetics data to optimize or predict precipitator performance (i.e. using simulation programs instead of performing full-scale experiments), is then possible.

\section{ACRUOULIDGEIRIT}

The author is grateful to Drs. G. A. Burney and D. A. Orth for many fruitful discussions on the solubility properties and precipitation characteristics of plutonium and cerium compounds. 
TABLE 6

Dissolution of 1.5 grams Cerium Oxalate in $20 \mathrm{~mL}$ Mitric Acid Solution

Acid Dissolution Time and Observation

\begin{tabular}{|c|c|c|}
\hline Conc. & $22^{\circ} \mathrm{C}$ & $50^{\circ} \mathrm{C}$ \\
\hline $3 \mathrm{M}$ & solids remain after $30 \mathrm{~min}$ & solids remain after $30 \mathrm{~min}$ \\
\hline $6 M$ & solids remain after $30 \mathrm{~min}$ & 90 seconds* \\
\hline $8 M$ & 4 minutes & 60 seconds** \\
\hline $12 \mathrm{M}$ & 3 minutes & 30 seconds \\
\hline $16 M$ & 2 minutes & $\begin{array}{l}10 \text { seconds with large amount } \\
\text { of } \mathrm{NO} \text { Xas evolved }\end{array}$ \\
\hline
\end{tabular}

* reprecipitation occurred after diluting ( $\left.10 \mathrm{~mL} \mathrm{H}_{2} \mathrm{O}\right)$ and cooling ** no reprecipitation observed after diluting and cooling 


\section{HOMENCLATURE}

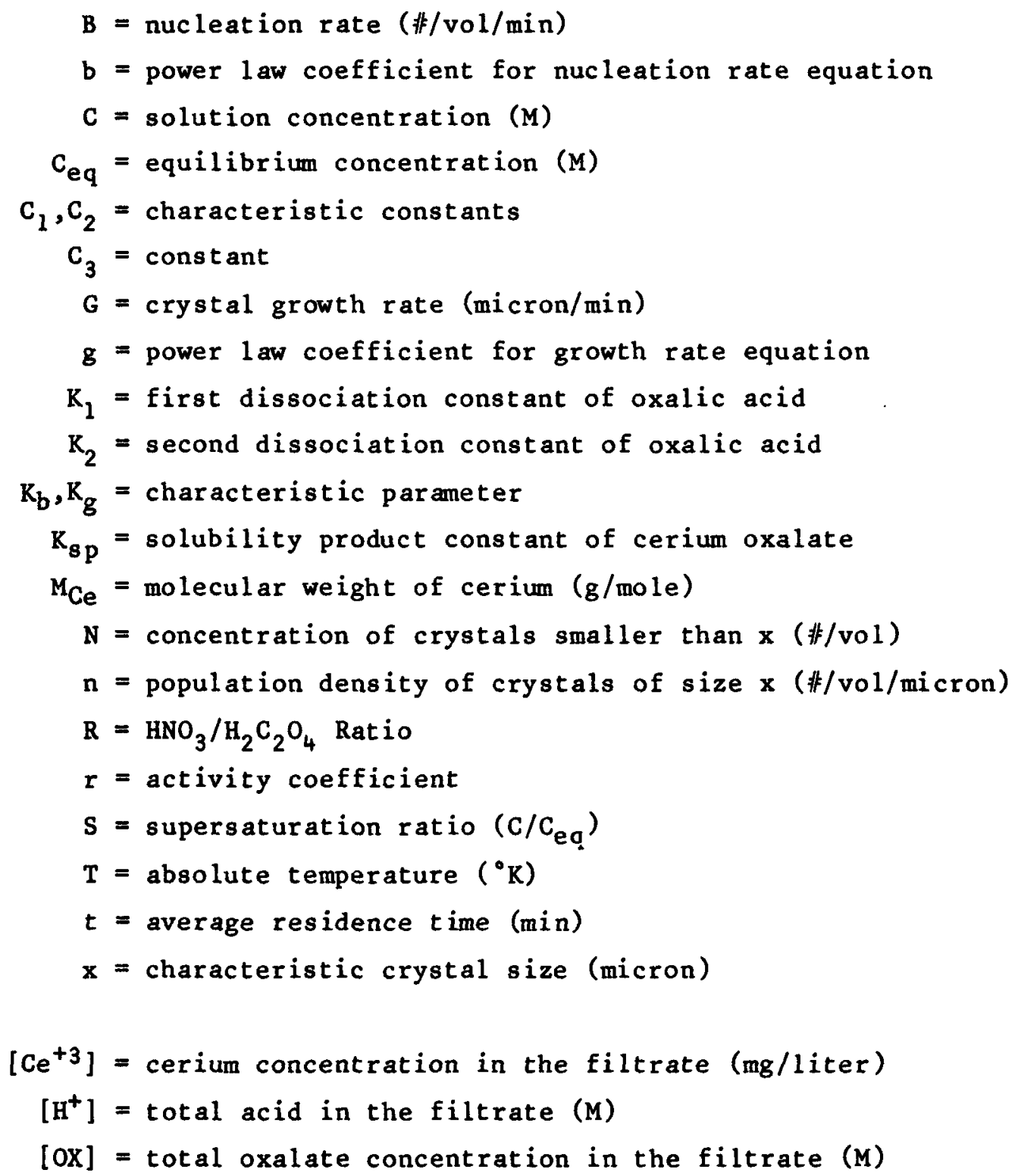




\section{REFERTICES}

1. D. W. Luerkens, Two-Stage Precipitation of Plutonium Trifluoride. USDOE Report DP-1680, E. I. du Pont de Nemours and Company, Savannah River Laboratory, Aiken, SC (1984)

2. D. W. Luerkens, Two-Stage Precipitation of Cerium Trifluoride. USDOE Report DP-1684, E. I. du Pont de Nemours and Company, Savannah River Laboratory, Aiken, SC (1984).

3. P. V. Danckwerts, App1. Sci. Res., A3, 1958.

4. T. P. Chang, Mixing and Solid Suspension in a Stirred Precipitator. USDOE Report DP-1721, E. I. du Pont de Nemours and Company, Aiken, SC (1986).

5. A. D. Randolph and M. A. Larson, Theory of Particulate Processes. Academic Press (1971)

6. J. Garside, "Industrial Crystallization from Solutions," Chem. Eng. Sci. 40, (1985)

7. A. G. Wilton, Nucleation. Macel Dekker, (1969).

8. M. Ohara and R. C. Reid, Modelling Crystal Growth Rates from Solutions. Prentice-Hall (1973).

9. P. Bennema and G. H. Gilmer, Crystal Growth, An Introduction. North Holland (1973).

10. P. T. Chiang, "Controlling Nucleation, Growth, and particle Size Distribution in Ammonium Diuranate Precipitation." Advances in Crystallization from Solutions. AIChE Symposium (1984).

11. H. M. Hulburt, "Perspectives on Crystallization in Chemical Process Technology." Advances in Crystallization from Solutions. AIChE Symposium (1984).

12. J. A. Porter, The Stability of $\mathrm{PuF}_{3}$ in the Trifluoride Precipitation Process. USDOE Report DP-621, E. I. du Pont de Nemours and Company, Savannah River Laboratory, Aiken, SC (1961).

13. G. A. Burney and F. W. Tober, Precipitation of Plutonium Trifluoride for Isolation of the Metal. USDOE Report DP-322, E. I. du Pont de Nemours and Company, Savannah River Laboratory, Aiken, SC (1958). 


\section{REFERAGES, Contd}

14. G. A. Burney and J. A. Porter, "Solubilities of Pu(III), $\mathrm{Am}$ (III), and $\mathrm{Cm}$ (III) 0xalates." Inorg. Nucl. Chem. Letter, 3 (1967).

15. CRC Handbook of Chemistry and Physics, CRC Press, 1986

16. A. E. Nielsen, Kinetics of Precipitation. Pergamon Press (1964). 